\title{
Can we recruit to expertise trials? Experience from the total or partial knee arthroplasty trial (TOPKAT)
}

\author{
Loretta Davies ${ }^{*}$, Cushla Cooper, TOPKAT Study Group, David Beard \\ From 2nd Clinical Trials Methodology Conference: Methodology Matters \\ Edinburgh, UK. 18-19 November 2013
}

The difficulties of conducting a randomised controlled trial (RCT) of a surgical intervention have long been recognised. Individual surgeon skill and experience introduce an additional challenge to those of conventional RCTs and as a consequence, surgeons may be reluctant to participate in orthopaedic surgery trials.

The use of expertise based randomised trials has been proposed as an alternative design, where participants are randomised to surgeons with an expertise in the allocated intervention.

TOPKAT, a randomised controlled trial examining the clinical and cost effectiveness of total or partial knee replacements for medial compartment osteoarthritis utilised a combined expertise/equipoise based design in order to maximise surgeon participation and recruitment to the study. The trial is on-going and has currently enrolled 460/500 (92\%) participants with recruitment due to end in September, 2013. Overall, there are twenty eight participating sites, twenty one of which are equipoise and remaining seven expertise sites.

Large variability in recruitment rates are seen across all sites with those participating as expertise sites demonstrating lower average monthly recruitment rates. Factors identified as additional challenges impacting recruitment rates and trial conduct to those of the equipoise sites include delays in establishing local expertise teams, patient preference for the recruiting surgeon, difficulties with patient logistics and timing of randomisation.

The TOPKAT trial demonstrates that recruitment of Orthopaedic surgeons to participate in and recruit to an expertise based design is both achievable and feasible. We highlight the potential challenges and possible

University of Oxford, Oxford, UK

(c) 2013 Davies et al; licensee BioMed Central Ltd. This is an Open Access article distributed under the terms of the Creative Commons Attribution License (http://creativecommons.org/licenses/by/2.0), which permits unrestricted use, distribution, and reproduction in any medium, provided the original work is properly cited. considerations that may facilitate the conduct of expertise based trials.

Published: 29 November 2013

doi:10.1186/1745-6215-14-S1-0114

Cite this article as: Davies et al:: Can we recruit to expertise trials? Experience from the total or partial knee arthroplasty trial (TOPKAT).

Trials 2013 14(Suppl 1):0114.

Submit your next manuscript to BioMed Central and take full advantage of:

- Convenient online submission

- Thorough peer review

- No space constraints or color figure charges

- Immediate publication on acceptance

- Inclusion in PubMed, CAS, Scopus and Google Scholar

- Research which is freely available for redistribution Submit your manuscript at
www.biomedcentral.com/submit C Biomed Central \\ () Biomed Central}

